\title{
INOVASI PEMBELAJARAN IPA (FISIKA) DI SD DENGAN PEMANFAATAN KIT ALTERNATIF DAN ALAT SEDERHANA YANG BERASAL DARI LINGKUNGAN
}

\section{SCIENCE LEARNING INNOVATION (PHYSICS) IN ELEMENTARY SCHOOLS BY UTILIZING ALTERNATIVE KITS AND SIMPLE TOOLS ORIGINATING FROM THE ENVIRONMENT}

\author{
Syahrial A, Muh.Makhrus, Sutrio, I Wayan Gunada, dan Muhammad Taufik \\ Program Studi Pendidikan Fisika FKIP Universitas Mataram, Mataram, Indonesia \\ Email : syahrial_ayub@unram.ac.id
}

Diterima: 5 November 2019. Disetujui: 3 Desember 2019. Dipublikasikan: 9 Januari 2020

\begin{abstract}
Abstrak : Telah dibuat Kit IPA Alternatif untuk inovasi pembelajaran IPA di Sekolah Dasar (SD). Kit IPA ini dibuat dengan memanfaatkan bahan-bahan dari lingkungan sekitar dan sangat mudah mendapatkan. Kit IPA ini dapat menjadi pilihan bila di suatu sekolah tidak mempunyai Kit-Kit yang dari pabrik (Kit INPRES dan Kit SEQIP) sehingga tidak ada alasan bagi guru untuk tidak mengajar dengan variatif. Ada beberapa manfaat yang didapat dengan dibuat dan diterapkannya Kit IPA alternatf ini dalam pembelajaran di sekolah, yaitu: (1) Kegiatan belajar mengajar akan lebih bermakna jika melibatkan seluruh indera. Dengan melihat, mendengar, merasakan, mengamati dan mengalami atau mempraktekkan sendiri, siswa akan mengalami internalisasi konsep pemebalajaran IPA secara mendalam, (2) Akan lebih menyenangkan dan mengesankan bagi siswa jika alat yang ada di Kit ini dikemas oleh guru dalam bentuk permainan, dan suasana kompetisi yang sehat untuk maju bersama, (3) percobaan-percobaan IPA yang didesain dengan menggunakan Kit ini diharapkan dapat menumbuhkembangkan dan melatih sikap ilmiah siswa dan menemukan konsep IPA seperti: proses letusan gunungapi, pembentukan batuan beku, kapal selam sederhana, aliran air, kalorimeter sederhana, lampu stopan sederhana, pembangkit listrik tenaga angin, tekanan hidrostatis, dan lainnya. Kit IPA Alternatif ini juga dilengkapi dengan buku petunjuk yang berisi: Kelas/Semester, Indikator, Tujuan Pembelajaran, Saran penerapan dalam pembelajaran, Alat dan bahan, Prosedur, Pertanyaan dan Penjelasan. Respon peserta didik terhadap inovasi pembelajaran IPA dengan Kit IPA alternatif sangat baik $(78,06 \%)$.
\end{abstract}

Kata kunci: Inovasi Pembelajaran IPA, Kit IPA Alternatif, Alat Sederhana, Lingkungan

\begin{abstract}
Alternative Science kits are made for science learning innovations in elementary schools. This Natural Science Kit is made using materials from the surrounding environment and is very easy to get. This Natural Science Kit can be an option if in a school does not have Kit from the factory (INPRES Kit and SEQIP Kit) so there is no reason for teachers not to teach varied. There are several benefits to be gained by making and implementing this alternative Science Kit in learning in schools, namely: (1) Teaching and learning activities will be more meaningful if they involve all the senses. By seeing, hearing, feeling, observing and experiencing or practicing on their own, students will experience internalization of the concept of learning science in depth, (2) It will be more fun and impressive for students if the tools in this Kit are packaged by the teacher in the form of a game, and a healthy competition atmosphere to move forward together, (3) science experiments designed using this kit are expected to develop and train students' scientific attitudes and discover science concepts such as: the process of volcanic eruptions, the formation of igneous rocks, simple submarines, water flow, simple calorimeters, simple stopan lights, wind power plants, hydrostatic pressure, and others. This Alternative Science Kit also comes with a user manual that contains: Class / Semester, Indicators, Learning Objectives, Suggestions for application in learning, Tools and materials, Procedures, Questions and Explanation. Students' responses to the innovation of science learning with alternative science kits are very good (78.06\%).
\end{abstract}

Keywords: Science Learning Innovation, Alternative Science Kit, Simple Tools, Environment

\section{PENDAHULUAN}

Pengajaran IPA seharusnya menempatkan aktivitas nyata siswa dalam berbagai objek yang dipelajari. Konsep, hukum dan teori tidak seharusnya diajarkan pada siswa sebagai pengetahuan yang sudah jadi dan harus dihapalkan, melainkan kesempatan harus diberikan kepada siswa untuk bersentuhan langsung dengan objek yang dipelajarinya [1]. Sehingga siswa belajar tentang bagaimana mendapatkan pengetahuan. Dalam pencarian pengetahuan, guru mempunyai kesempatan untuk memperhatikan dan membimbing sikap dan perilaku siswa. Siswa dibimbing untuk melakukan penelusuran masalah, mencari berbagai penjelasan mengenai fenomena yang mereka lihat, mengembangkan kemampuan fisik (motorik) dan melatih penalaran siswa untuk memecahkan masalah dengan melakukan berbagai eksperimen yang relevan. Salah satu media yang tepat untuk melakukan pembelajaran seperti yang dipaparkan di atas adalah pembelajaran yang memanfaatkan kit 
dan alat sederhana. Kit yang dibuat adalah kit alternatif yang bahan-bahannya mudah didapat.

Berdasarkan hasil monitoring yang dilakukan oleh Dirjen Pendidikan Dasar dan Menengah tahun 2000, ditemukan bahwa kit IPA belum digunakan dalam pembelajaran di kelas, hasil penataran belum diimplementasikan secara optimal dan kegiatan belajar mengajar (KBM) di kelas cenderung kembali ke pola sebelum penataran diberikan. Hal yang serupa, juga ditemukan di kota Mataram, Provinsi Nusa Tenggara Barat (NTB). Dari hasil penelitian yang dilakukan oleh Syahrial pada tahun 2001[2] , ditemukan fakta bahwa peralatan IPA yang ada di sekolah jarang digunakan oleh guru dalam KBM. Penyebabnya adalah guru pada umumnya kurang menguasai konsep-konsep IPA dan cara merangkai percobaan IPA dengan kit dengan baik dan benar. Di samping itu, dari hasil observasi mengenai ketersedian kit IPA untuk tingkat sekolah dasar (SD) di kota Mataram ditemukan bahwa $60 \%$ sekolah belum mempunyai kit IPA. Oleh karena itu perlu dipikirkan kit alternatif dan alat sederhana yang dapat menggantikan kit IPA dan menanamkan konsep yang sama. Data statistik NTB melaporkan bahwa terdapat $58 \%$ guru yang tidak layak, dimana kelemahan terbesar terjadi pada sisi kompetensi kualitas pengajaran [3]. Kelemahan ini dapat berpengaruh negatif terhadap komponen lain dalam sistem yang kolaboratif, sebab ketidakmampuan guru dalam mengajar sesuai dengan tuntutan kurikulum akan berakibat fatal bagi penanaman konsep-konsep dasar ke anak didik. Berdasarkan hal itu, maka kelemahan guru pada tercapainya kompetensi pengajaran yang berkualitas memerlukan penanganan segera dan akurat melalui produk penelitian yang tepat. Rumusan masalah yang diajukan pada penelitian ini untuk tahun pertama adalah sebagai berikut:

a. Bagaimana desain percobaan IPA dengan memanfaatkan alat sederhana yang berasal dari lingkungan untuk pembelajaran IPA SD yang inovatif?

b. Bagaimana respon peserta didik terhadap skenario pembelajaran IPA yang inovatif dan desain alat sederhana yang berasal dari lingkungan serta integrasinya dalam pembelajaran IPA di SD?

Manfaat yang dapat diperoleh dari penelitian ini adalah:

1. Bagi siswa SD, dari penelitian ini diharapkan:

a) Siswa dapat menggunakan kit alternatif dan alat sederhana yang berasal dari lingkungan dan melakukan percobaan dalam suasana menyenangkan dan menarik.

b) Siswa belajar untuk mendapatkan pengetahuan dari pengamatan secara langsung. c) Siswa dapat termotivasi untuk dapat berpikir kreatif dan memberikan keterampilan hidup bagi siswa.

d) Siswa mampu membuat kesimpulan dari percobaan yang dilakukannya.

e) Sehingga pada akhirnya terjadi peningkatan terhadap hasil belajar siswa pada mata pelajaran IPA.

2. Bagi guru SD, dari penelitian ini diharapkan:

a) Guru mampu menggunakan kit alternatif dan alat sederhana yang berasal dari lingkunan.

b) Guru mampu menanamkan konsep-konsep IPA melalui penggunaan kit alternatif dan alat sederhana.

c) Guru mampu menciptakan suatu pembelajaran IPA yang berorientasi kepada siswa.

d) Kompetensi guru dalam pengajaran yang berkualitas dapat meningkat.

e) Pada akhirnya dapat meningkatkan profesionalisme guru.

Ilmuwan pada umumnya bekerja hanya menguasai sejumlah kemampuan atau keterampilan fisik dan mental tertentu saja. Kebanyakan ilmuwan justru mendapatkan penemuan baru tanpa menguasai semua fakta dan konsep yang terhimpun dalam suatu cabang atau disiplin ilmu. Malahan penguasaan fakta dan konsep yang terlalu banyak dan mendalam justru menghambat daya ciptanya untuk menemukan halhal yang baru [4]. Berdasarkan hal ini, maka dalam penyajian materi pelajaran hendaknya dirancang dan didesain untuk menambah rasa ingin tahu siswa.

Rasa ingin tahu tersebut hendaknya dikembangkan untuk seluruh mata pelajaran. Belajar merupakan proses yang aktif yakni proses melihat, mengamati dan memahami sesuatu serta proses berbuat melalui pengalaman. Dengan kata lain dalam proses pengajaran yang menjadi persoalan utama adalah adanya proses berubahnya tingkah laku siswa melalui pengalaman yang diperolehnya. Pengajaran IPA yang utuh adalah pengajaran yang mengangkat tiga hakekat IPA, yakni mengembangkan pemahaman para peserta didik tentang alam, mengembangkan keterampilan-keterampilan yang diperlukan untuk memperoleh atau mengembangkan pengetahuan yang baru, dan mengembangkan sikapsikap positif. Olehkarena itu konsep, hukum dan teori tidak seharusnya diajarkan kepada siswa sebagai suatu pengetahuan yang diingat-ingat, melainkan perlu diusahakan agar siswa juga belajar bagaimana mendapat pengetahuan dengan menempatkan aktifitas nyata siswa dengan berbagai objek yang dipelajari baik di laboratorium, di kelas maupun di lingkungan sekolah.

Ada lima macam hasil belajar yakni informasi, keterampilan intelektual, strategi kognitif, sikap dan keterampilan motorik. Informasi verbal adalah informasi yang diperoleh dari kata yang 
diucapkan orang, informasi ini meliputi fakta-fakta atau konsep-konsep [5]. Keterampilan intelektual meliputi bagaimana membedakan, menunjukkan suatu konsep konkrit. Strategi kognitif dalam pembelajaran IPA adalah membuat suatu perencanaan untuk memecahkan masalah. Sikap merupakan pembawaan yang dapat dipelajari, yang dapat mempengaruhi tingkah laku terhadap kejadian kejadian. Sedangkan keterampilan motorik mencakup kegiatan-kegiatan fisik seperti berbicara, menulis dan menggunakan peralatan. Salah satu usaha dalam mencapai hasil belajar ini, adalah melalui pengadaan alat-alat peraga IPA (kit IPA) untuk SD. Untuk tidak menimbulkan keraguan perlu kiranya dirumuskan apa yang dimaksud dengan kit IPA. Kit berarti kotak, sehingga kit IPA dapat diartikan sebagai kotak yang berisi seperangkat alatalat IPA. Dalam Webster's New Collegiate Dictionary dijelaskan bahwa: Kit is box, bag in which such a Kit is carried, [6]. Sehingga kit IPA dapat didefinisikan sebagai kotak yang berisi seperangkat alat-alat IPA yang mudah dikemas dan dibawa ke dalam kelas saat mengadakan percobaan atau kegiatan belajar mengajar (KBM). Dengan memanfaatkan kit IPA yang tersedia, siswa dapat berhadapan dengan peralatan secara langsung dan melakukan percobaan. Hal ini dapat memberikan manfaat yang cukup besar bagi siswa. Dimana, siswa dapat mencoba, mengalami dan berbuat sesuai dengan kegiatan yang dilakukan oleh ilmuwan ketika bekerja. Untuk membimbing dan mengarahkan siswa untuk melakukan percobaan, sangatlah diperlukan penuntun atau petunjuk yang berisi uraian singkat tentang apa yang harus dilakukan siswa. Melalui pembelajaran ini diharapkan dapat mengubah pola mengajar dari teacher oriented menjadi student oriented, mengembangkan keterampilan proses, mengembangkan sikap ilmiah, serta membangkitkn rasa cinta siswa terhadap alam sekitar. Bila dikaji lebih mendalam, ternyata kit IPA banyak memberi keuntungan bagi siswa, seperti siswa dapat terlibat secara langsung dalam melakukan percobaan. Hal ini merupakan pendekatan multisensorik dalam arti siswa dapat mendengar, melihat dan meraba, sehingga diharapkan dapat meningkatkan keterampilan dan menciptakan suasana yang akrab.

Prestasi belajar merupakan akumulasi dari kesanggupan siswa untuk menyerap informasi yang diterimanya. Hasil yang diperoleh setiap siswa, dalam suatu mata pelajaran belum tentu sama. Kemampuan yang diharapkan dari diri siswa pada hakekatnya adalah prestasi belajar yang diinginkan. Prestasi belajar ini mencakup tiga domain, yaitu kognitif (penalaran), afektif (sikap) dan psikomotor (bertindak), [7]. Prestasi belajar selayaknya memunculkan ketiga domain secara serentak. Ketiga domain ini, dapat diukur dengan melakukan tes terhadap siswa. Oleh karena itu, untuk mencapai ketiga domain tersebut, memanfaatkan penggunaan kit IPA dan alat sederhana merupakan jawaban yang tepat. Penelitian ini merupakan pengembangan dari penelitian yang telah dilakukan sebelumnya mengenai skenario pembelajaran yang berorientasi pada pemanfaatan kit IPA. Berdasarkan penelitian [8], penerapan model pembelajaran yang mengoptimalkan penggunaan kit IPA dapat meningkatkan keterampilan siswa dalam pemakaian alat percobaan IPA, dimana model pembelajaran yang berorientasi kepada siswa mendapat respon yang sangat baik dari siswa dan dapat meningkatkan prestasi belajar siswa [9]. Kemudian dari hasil studi penggunaan kit IPA di kota Mataram ditemukan fakta bahwa jarangnya pemakaian kit IPA SD dalam pembelajaran di kelas [10]. Untuk menindaklanjuti terhadap hasil-hasil dari penelitian tersebut, dirasakan sangat perlu untuk dilakukan penelitian pengembangan yang menghasilkan produk nyata alat sederhana dari lingkungan. Indikator keberhasilan penelitian pengembanga ini adalah, maka dapat ditinjau dari data kualitatif (aktivitas pembelajaran semakin baik melalui penggunanan kit IPA alternatif dan alat sederhana) dan data kuantitatif (terjadi peningkatan prestasi belajar siswa yang tercermin dari nilai rata-rata siswa untuk pelajaran IPA di SD dan menurunya jumlah siswa yang memperoleh nilai di bawah minimal yang telah ditetapkan yaitu 70 untuk skala penilaian 100).

\section{METODE PENELITIAN}

Penelitian ini adalah penelitian pengembangan yang dilakukan 6 tahap, yaitu: (1) Reseach and information collecting, (2) Planning, (3) Develop preliminary form of product, (4) Prelimary field testing, (5) Main Product revision, (6) Operational field testing and final product revision[11]. Pada tahap (1) dilakukan penggalian informasi tentang jumlah sekolah yang mendapat kit IPA, penerapan kit IPA pada pembelajaran dan studi tentang penggunaan kit IPA di sekolah kota Mataram.

Data studi awal dan literatur ini akan menjadi informasi awal dalam mengembangkan kit alternatif di sekolah dasar. Tahap ke (2) berdasarkan studi awal dan literatur yang sudah dianalisis, tim merancang kit alternatif yang bahan-bahannya berasal dari lingkungan sekitar. Setelah itu baru disusun draft awal rencana pelaksanaan pembelajaran yang mengintegrasikan kit alternatif. Tahap (3) bentuk permulaan kit IPA alternatif telah dibuat dan telah divalidasi kelayakannya oleh para ahli. Pada tahap ini pula tim melakukan persiapan dokumen pendukung dan alat-alat pendukung untuk tahap implementasi. Tahap (4) tim melakukan implementasi pembelajaran dengan menggunakan Kit IPA alternatif dengan pedoman rencana pelaksanaan pembelajaran yang sudah dibuat. Pada tahap ini diperoleh data observasi pembelajaran, data evaluasi dan refleksi dari tim dan guru untuk 
implementasi berikutnya. Tahap (5) berdasarkan observasi, evaluasi yang dilakukan oleh tim dan guru serta refleksi yang sudah di implementasikan berulang sesuai indikator yang telah ditetapkan, tim menetapkan bentuk kit IPA alternatif di sekolah dasar. Tahap (6) produk kit IPA alternatif telah dihasilkan. Jika memungkinkan bisa dilakukan pengujian ulang untuk memantapkannya. Rencana pelaksanaan pembelajaran, yang akan menjadi pondasi bagi pengembangan model-model pembelajaran yang mengintegrasikan kit IPA.

Berdasarkan aspek-aspek yang diteliti tersebut, maka dalam penelitian ini akan dihasilkan: (a) percobaan dengan alat-alat sederhana yang berasal dari lingkungan dan dapat digunakan untuk pembelajaran IPA di SD, hal ini untuk mengantisipasi sekolah-sekolah yang belum memiliki kit IPA sehingga tidak menghalangi inovasi pembelajaran IPA. Temuan ini akan dibukukan sebagai pedoman bagi guru untuk membuatnya, (b) informasi tanggapan peserta didik terhadap inovasi pembelajaran IPA yang memanfaatkan kit alternatif dan alat sederhana dari lingkungan. Melalui pengisian kuesioner diperoleh data mengenai respon peserta didik terhadap penerapan skenario pembelajaran inovatif yang memanfaatkan kit IPA dan alat sederhana Kemudian data-data ini dianalisis secara deskriptif kualitatif dengan menggunakan skor dalam skala $1-5$, dimana skor $5=$ sangat baik, $4=$ baik, 3 = cukup, 2 = kurang dan $1=$ sangat kurang. Skor maksimal setiap item adalah 5 sehingga dari 20 item diperoleh skor maksimal 100. Analisis data respon siswa menggunakan $\mathrm{Mi}$ dan Si. Rerata $\mathrm{Mi}$ dapat dihitung dengan: $\mathrm{Mi}=1 / 2$ (Skor maksimal ideal). Sedangkan simpangan ideal Si dapat dihitung dengan: $\mathrm{Si}=1 / 3(\mathrm{Mi})$. Kriteria respon siswa ditentukan berdasarkan pedoman konversi berikut ini:

Tabel 1: Pedoman konversi penilaian skala 1-5

\begin{tabular}{lcl}
\hline \multicolumn{1}{c}{ Interval } & $\begin{array}{c}\text { Konversi } \\
\text { Nilai }\end{array}$ & Kriteria \\
\hline $\begin{array}{l}(\mathrm{Mi}+1,5 \mathrm{Si})-(\mathrm{Mi} \\
+3,0 \mathrm{Si})\end{array}$ & $76 \%-100 \%$ & Sangat baik \\
$(\mathrm{Mi}+0,5 \mathrm{Si})-(\mathrm{Mi}$ & $59 \%-75 \%$ & Baik \\
$+1,5 \mathrm{Si})$ & & \\
$(\mathrm{Mi}-0,5 \mathrm{Si})-(\mathrm{Mi}$ & $43 \%-58 \%$ & Cukup \\
$+0,5 \mathrm{Si})$ & & \\
$(\mathrm{Mi}-1,5 \mathrm{Si})-(\mathrm{Mi}$ & $25 \%-42 \%$ & Kurang \\
$-3,0 \mathrm{Si})$ & & \\
$(\mathrm{Mi}-3,0 \mathrm{Si})-(\mathrm{Mi}$ & $0 \%-25 \%$ & $\begin{array}{l}\text { Sangat } \\
\text { kurang }\end{array}$ \\
\hline$-1,5 \mathrm{Si})$ & & \\
\hline
\end{tabular}

[12].

Data prestasi belajar siswa setelah diterapkannya inovasi pembelajaran IPA ini juga akan dianalisa secara kuantitatif.

\section{HASIL DAN PEMBAHASAN}

Kit alternatif dari bahan bahan lingkungan dan mudah didapatkan yang berhasil dibuat oleh tim terdiri dari: (a) alat peraga proses terjadinya erupsi gunungapi. Miniatur gunungapi ini terbuat dari kertas koran yang sudah dirobek kecil-kecil dan dicampur dengan lem kertas. Alat ini mampu memperlihatkan kepada peserta didik proses terjadinya letusan gunungapi dan keluarnya magma. Proses ini terjadi dari reaksi pencampuran soda kue, asam sitrat dan air yang sudah diberi pewarna merah. Reaksi pencampuran ini akan menghasilkan ledakan kecil yang dibarengi dengan meluapnya cairan hasil reaksi keluar miniatur gunungapi. Hal ini akan memberikan pengalaman nyata kepada peserta didik tentang proses ledakan dan keluarnya magma pada aktifitas gunungapi yang sebenarnya.

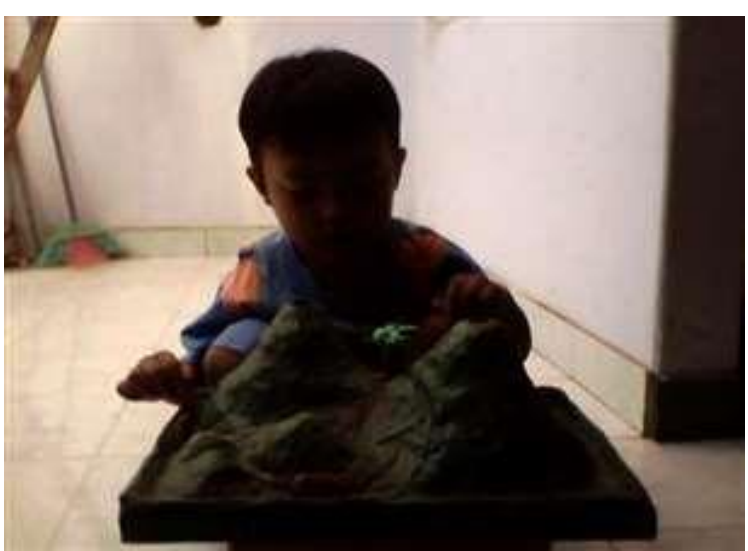

Gambar 1 : Alat Peraga Gunungapi

(b) Alat peraga kapal selam sederhana. Kapal selam sederhana ini terbuat dari berbagai jenis botol plastik yang disatukan dengan lem sehingga berbentuk kapal selam. Bagian dalam dari kapal selam ini diberi balon untuk zat pengapung. Alat ini mampu memperlihatkan kepada peserta didik bagaimana sebuah kapal selam bisa mengapung, melayang dan tenggelam di air. Hal ini akan memberikan contoh nyata kepada peserta didik sehingga konsep terapung, tenggelam dan melayang dapat dipahami dengan baik,

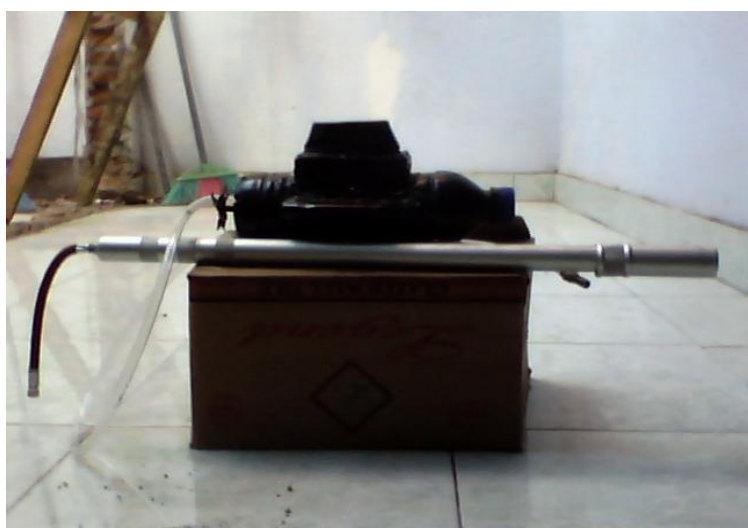

Gambar 2 : Alat Peraga Kapal Selam Sederhana 
(c) alat peraga aliran air. Alat peraga ini terbuat dari botol plastik dan selang plastik yang menghubungkan dua botol. Alat ini mampu memperlihatkan kepada peserta didik bahwa aliran air akan terjadi bila ada perbedaan tinggi permukaan air. Hal ini akan memberikan contoh nyata tentang konsep aliran air,

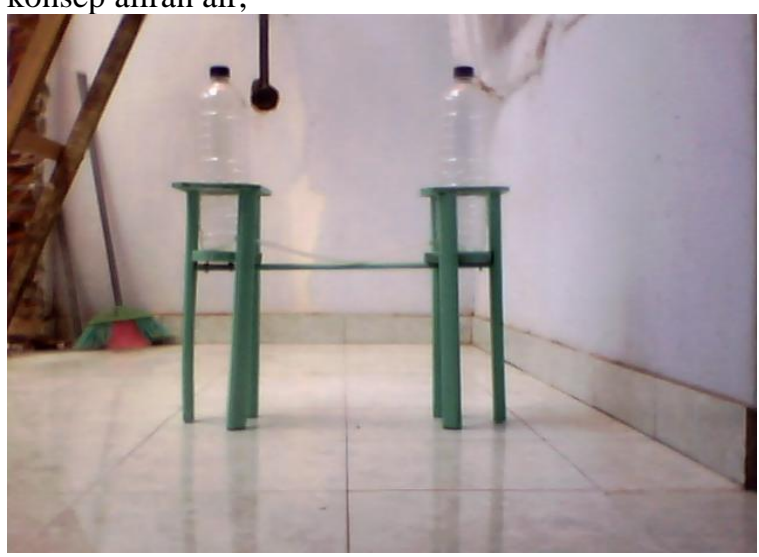

Gambar 3 : Alat Peraga Aliran Air

(d) alat peraga pembangkit listrik sederhana tenaga angin. Alat ini terbuat dari kayu dan plastik serta dinamo kecil sebagai pembangkit listriknya. Alat ini mampu memberikan contoh nyata kepada peserta didik tentang bagaimana listrik dihasilkan dan di alirkan ke rumah-rumah,

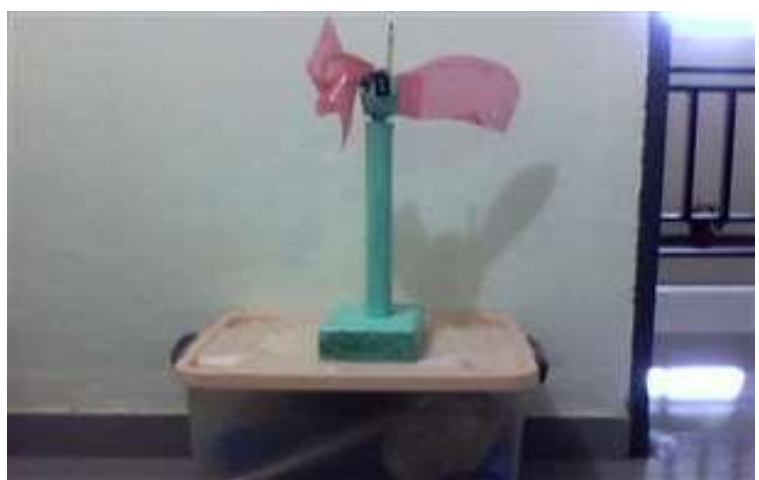

Gambar 4 : Alat Peraga Pembangkit Listrik

(e) Lampu stopan sederhana. Alat ini terbuat dari lampu led, mobil mobilan, kayu. Alat ini mampu memberikan pemahaman kepada peserta didik tentang rangkaian seri dan paralel dan penerapannya dalam kehidupan sehari-hari, sehingga peserta didik bisa memahami konsep lampu lalu lintas yang sering mereka temukan diperempatan lalu lintas.

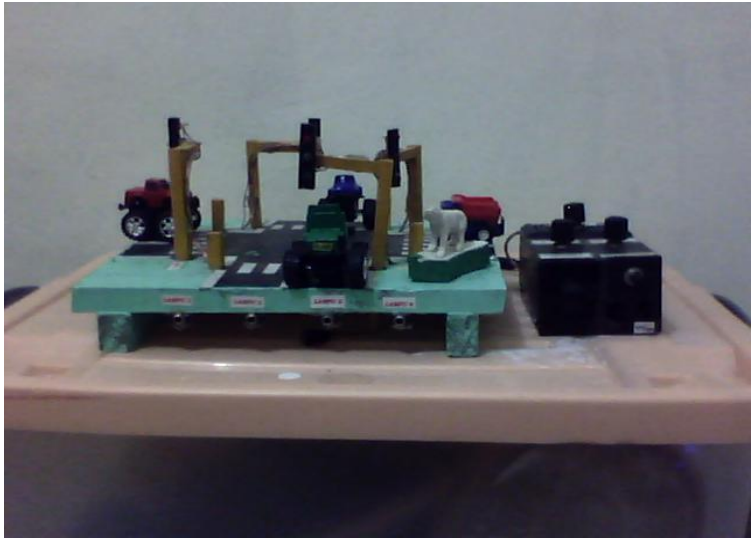

Gambar 5 : Alat Peraga Lampu Stopan Sederhana

Penerapan kit alternatif dalam pembelajaran dapat di masukkan pada kegiatan awal atau kegiatan inti atau kegiatan akhir, sangat tergantung pada tujuan, kreatifitas dan inovasi dari guru yang mengajar. Sebagai contoh, kit alternatif kapal selam sederhana dapat di gunakan sebagai contoh nyata aplikasi pembelajaran fluida pada konsep terapung, tenggelam dan melayang. Kapal selam sederhana ini dapat memberikan contoh nyata bagaimana sebuah kapal selam bisa mengapung, tenggelam dan melayang di air. Pertama tama masukkanlah kapal selam ini ke dalam air atau kolam kecil di halaman sekolah, akibat adanya lubang dan pemberat pada kapal selam maka air masuk saat kapal selam di letakkan. Masukknya air akan menambah berat kapal selam sehingga perlahan ia akan tenggelam. Untuk membuat terapung maka harus dipompakan udara (zat pengapung) ke dalamnya melalui selang yang sudah dibuatkan. Udara ditampung oleh balon yang ada di dalam kapal, dengan pemompaan ini akan menambah ukuran zat pengapung. Ukuran ini bisa kita atur supaya kapal menjadi melayang atau mengapung. Kapal selam sederhana dapat di integrasikan pada pembelajaran dikelas pada kegiatan akhir, yaitu aplikasi dari konsep terapung, tenggelam di air sehingga diharapkan siswa diberikan contoh yang agak nyata.

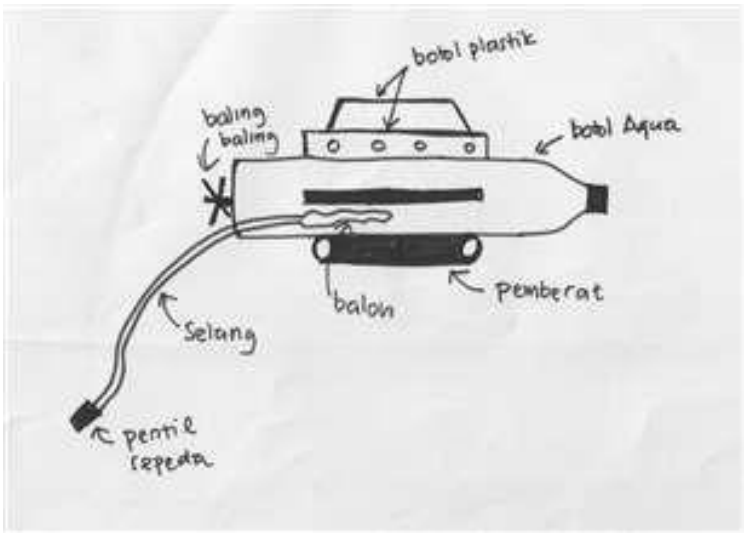

Gambar 6 : Sketsa Kapal Selam Sederhana 
Kit alternatif yang lain dapat diaplikasikan pada konsep-konsep lainnya sesuai dengan tujuan alat itu dibuat. Alat peraga gunungapi pada konsep kegunungapian, alat peraga pembangkit listrik dan lampu stopan sederhana pada konsep listrik, alat peraga aliran air pada konsep tekanan atau fluida.

Berdasarkan angket respon yang diberikan kepada peserta didik setelah penerapan kit alternatif pada pembelajaran di kelas didapatkan: (1) pembelajaran dan pemahaman materi $78 \%$ sangat setuju, (2) penerapan Kit Alternatif $85 \%$ sangat setuju, (3) lembar kerja peserta didik $72 \%$ sangat setuju dan, (4) evaluasi $70 \%$ sangat setuju. Jadi ratarata respon peserta didik terhadap penerapan kit alternatif pada pembelajaran di kelas adalah 76,25\% sangat setuju. Hasil ini berkorelasi dengan hasil penelitian sebelumnya [13-14]

\section{KESIMPULAN}

Berdasarkan hasil dan pembahasan sebelumnya, maka dapat disimpulkan penerapan kit alternatif pada pembelajaran sangat setuju dilakukan pada pembelajaran IPA (Fisika) di sekolah dasar. Kit alternatif dibuat dari bahan-bahan yang mudah didapatkan di lingkungan sekitar. Kit alternatif yang sudah dibuat berisi alat peraga kapal selam, alat peraga gunungapi, alat peraga pembangkit listrik, alat peraga aliran air dan alat peraga lampu stopan sederhana.

\section{DAFTAR PUSTAKA}

[1]. Klinger, Walter. 1997. Survey of Teaching Methods in Natural Sciences Erziehungswiss. Fakultat der Universtat: Erlangen-Nurnbe.

[2]. Syahrial A. (2001). Studi Penggunaan Kit IPA SD di Kodya Mataram. Mataram : Lembaga Penelitian Universitas Mataram.

[3]. Klinger. (1997). Survei Metoda Pengajaran dalam Ilmu Pengetahuan Alam. Jakarta : SEQIP

[4]. Semiawan, dkk. (1988). Pendidikan Keterampilan Proses. Jakarta: PT Gramedia.

[5]. Irawan, P. (1997). Teori Belajar. Jakarta: PAUPPAI Universitas Terbuka.

[6]. Merriem Webster. (1953). Webster's Dictionary. Miamy Florida: PSI and Ass Inc.

[7]. Winataputra. (1996). Belajar dan Pembelajaran MIPA. Jakarta : Universitas

[8]. Syahrial A. (2003). Peningkatan Kualitas Proses Belajar Mengajar IPA Melalui Optimalisasi Penggunaan Kit IPA di SLTP Negeri 6 Mataram. Mataram: Lembaga Penelitian Universitas Mataram.

[9]. Syahrial A. (2003). Optimalisasi Pembelajaran Fisika di SLTP dengan Menggunakan Model Pembelajaran yang Berorientasi Kepada Siswa (Student Oriented). Mataram: Lembaga Penelitian Universitas Mataram
[10].Syahrial A. (2005). Peningkatan Kualitas Pembelajaran Fisika di SMA Negeri 2 Mataram Melalui Implementasi Kurikulum 2004 dalam Skenario Pembelajaran yang Berorientasi kepada Pendekatan Keterampilan Proses. Mataram: Lembaga Penelitian Universitas Mataram.

[11]. Borg.WR \& Gall. MD. (1983). Educational Reseach. New York: Longman

[12]. Nurkencana, dkk. (1986). Evaluasi Pendidikan. Jakarta: Usaha Offset Print

[13]. Auliya, M., \& Kosim, K. (2017). Pengembangan Modul Fisika Materi Optik Dengan Pendekatan Saintifik Berbasis Fenomena Alam Untuk Meningkatkan Efektivitas Belajar Siswa SMA. Jurnal Pijar Mipa, 12(2), 71-80.

[14]. Hikmawati, H., \& Azmi, S. (2011). Model Peraga Sebagai Media Pembelajaran Pada Mata Pelajaran Sains Dan Matematika Di Sekolah Menengah Pertama. Jurnal Pijar Mipa, 6(1). 